\title{
A Life for Organic Synthesis - Dieter Seebach at 65
}

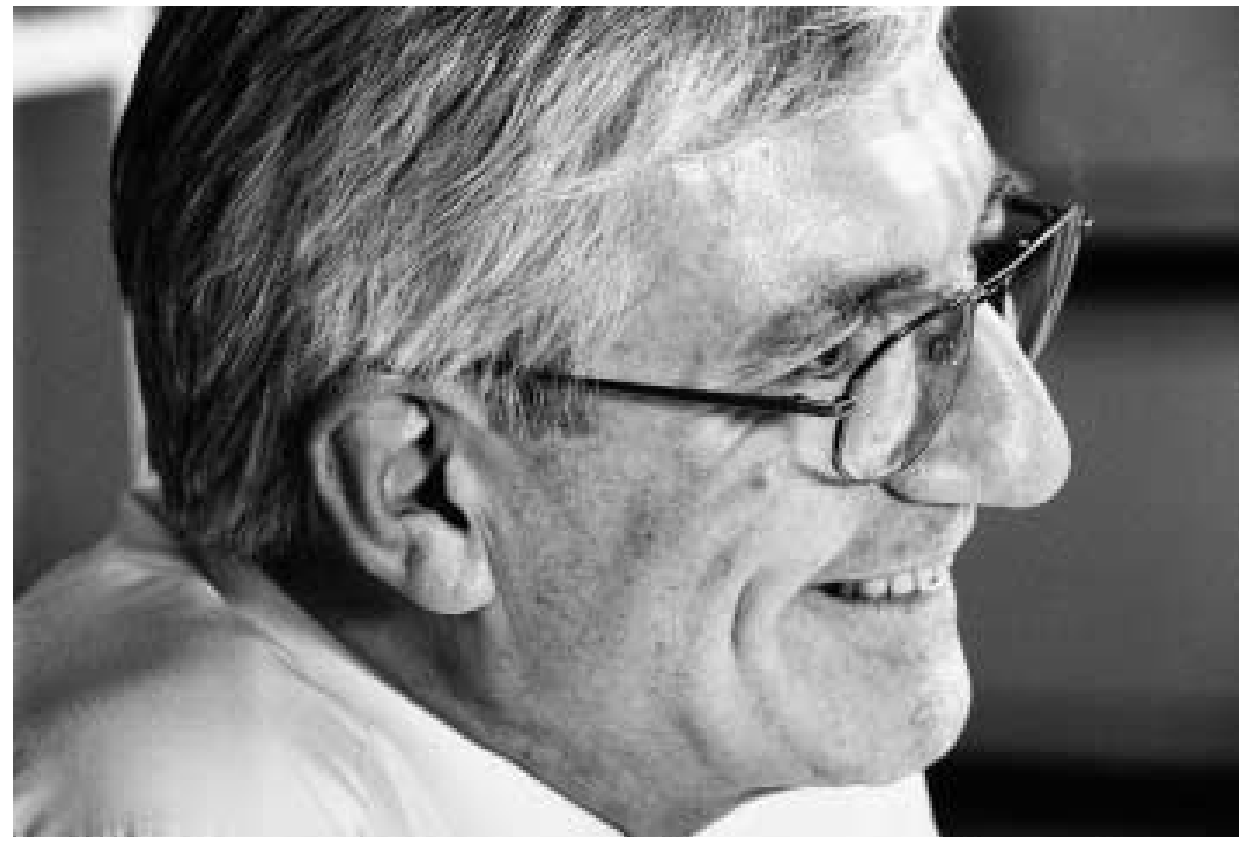

On October 31, 2002, Dieter Seebach will turn 65. As a consequence, he will have to relinquish his professorship of organic chemistry at ETH Zürich at the end of the winter term 2002/03. While outsiders might consider this to be a needless and severe disruption of a scientific career, his retirement will also relieve him from administrative duties and the concomitant tedious routine, thereby enabling him to focus solely on research, albeit with somewhat diminished resources. The landmark character of his retirement for the chemical community worldwide and Swiss academia in particular makes this the appropriate moment to reflect on his profound impact as scientist, teacher and consultant in academia as well as the chemical industry.

The cornerstones of Dieter Seebach's academic career shall be briefly narrated here [1]: Born and raised in Karlsruhe, Germany, he studied chemistry at the Technische Hochschule Karlsruhe from 1956 to 1961. Upon joining the group of Rudolf Criegee, he worked in the field of organic peroxides both for his diploma and Ph.D. thesis. After having received his Ph.D. in 1964, he spent 18 months as a postdoctoral fellow and lecturer at Harvard University in the group of E.J. Corey, where he initiated 1,3-dithiane chemistry. Returning to his alma mater, in the meantime renamed Universität Karlsruhe (TH), he started an independent research program on carbanion chemistry which eventually earned him the degree 'Privatdozent' in 1969. Just two years later, he was appointed full professor of organic chemistry at the Justus LiebigUniversität Giessen as one of the youngest chemistry professors in Germany at that time. In 1977, he accepted an offer to become Vladimir Prelog's successor as professor of chemistry at the Laboratorium für Organische Chemie at ETH Zürich. During his long tenure, he also served as head of the institute (1984/85 and again in 1991/92 - unlike serving a prison sentence where good behavior leads to reduced time, good behavior as head of institute may lead to reappointment or a longer period of service) and chairman of the chemistry department (1994-96).

The sheer scope and volume of $D$. Seebach's achievements makes a detailed survey of his scientific work an intimidating task. Specifically, the enormous and diverse range of research areas on which he has left his mark precludes the identification of his name with a single, particular subject. Being one of the few scientists who have continually summarized the progress made in a specific area in a large number of review articles, he has produced a truly remarkable number of such articles. A complete list of publications labeled as reviews in his personal publication list [2] is given in the references section [3-68]. These reviews may serve as flagpoles for a journey through the numerous research areas on which $D$. Seebach has left an indelible stamp. Taking one of the most prominent publication media, Angewandte Chemie, as a yardstick, a statistical survey [69] of all review articles published in this journal (up to July 11, 2002) reveals that Dieter Seebach, together with Fritz Vögtle, heads the list of the most productive contributors with eleven reviews each.

Next to Angewandte Chemie, this very journal, Chimia, has been his favorite forum for publishing reviews, resulting in a total of nine contributions over the past 25 years. The topics covered by these accounts range from nitroaliphatic com- 
pounds in synthesis via organic reactions carried out at ultra-low temperatures to his recent areas of interest such as polyhydroxyalkanoates, TADDOL chemistry and $\beta$ - and $\gamma$-peptides. His solidarity with the Swiss chemical community is also evident from his frequent participation in the International Workshop on Modern Synthetic Methods held in Interlaken between 1976 and 1995, resulting in five contributions for the MSM series (of a total of seven!) [14][18][22][30][38]. The total number of pages written for these books amounts to 660, an impressive array of mechanistic discussions and detailed reaction procedures, always putting the work in perspective with the current state of the art of organic synthesis.

The large number of contributions (14) for the Encyclopedia of Reagents for Organic Synthesis (EROS) form a special subgroup in this context since they provide a handy collection of useful reagents developed in the Seebach group over many years. These lasting contributions to the art of organic synthesis comprise $t$-butyl 2- $t$-butyl3-methyl-4-oxo-1-imidazolidinecarboxylate (Boc-BMI), lithium- $\alpha$-lithiomethanenitronate, 2,2-dimethyl- $\alpha, \alpha, \alpha^{\prime}, \alpha^{\prime}$ - tetraphenyl1,3-dioxolane-4,5-dimethanolatotitanium diisopropoxide, and N,N'-dimethylpropyleneurea (DMPU), among others [39-52]. Obviously missing here are prominent and useful reagents closely linked with Seebach's name such as 1,3-dithianes and their derivatives, the description of which he handed over to former co-workers to give credit for their respective contributions. A further rich source of synthesis-related information are the ten Tetrahedron Symposia-in-Print publications [19][23][26] [29][70-75] the first four of which bear distinct review character. A closer look at the subjects of these symposia again demonstrates the extraordinary wide range of topics for which $D$. Seebach was deemed the leading authority by the respective editors.

At this point we would like to observe that many of the more than 700 papers coming from the Seebach group are so replete with experimental details, insightful footnotes and all-embracing literature coverage that they could, with some justification, be granted review status. In fact, CAS indexes a full paper on the diastereoselective synthesis of nitroaldol derivatives [76] as a review article. Also beyond review status, the 14 contributions written for Organic Syntheses serve as a demonstration for the wide applicability and usefulness of the synthetic methodology developed in his group [77-90]. The group of compounds described herein reflects the large number of synthetic methods that over the years have made $D$. Seebach a household name for organic chemists both in academia and industry. The acid test for the value and effectiveness of synthetic methodology has always been its application in a complex natural product synthesis, and therefore several projects of this kind were pursued in the Seebach group. Two classes of natural products attracted particular attention, namely macrodiolides and macrolides. Within this context, among others, pyrenophorin, colletodiol, and elaiophylin [91] as well as gloeosporon [92] and myxovirescin [93] were synthesized.

A detailed examination of D. Seebach's scientific output is well beyond the scope of the present appreciation. Readers with an interest in a 'guided tour' through his lifework are therefore referred to a very personal account he presented when being awarded the Marcel Benoit prize 2000 (the 'Swiss Nobel prize') [61]. Without going into details, his general influence on the scientific community can be deduced from the references made to his work in the chemical literature [69]. An obvious source of reference for his main areas of interest are the above-mentioned 66 reviews; the ten most cited of which are listed in Table 1 . The reviews published in Angewandte Chemie feature prominently among them - seven out of ten! - which is not unexpected due to the high impact factor of this particular journal. It may come as a surprise that D. Seebach's most cited publication is not the comprehensive review on umpolung the topic his name is probably most often associated with - but the 1988 account on the structures of lithium enolates published almost ten years later. Coming third is the unique collaboration from the 'holy grail of stereochemistry' resulting in the unambiguous specification of the steric course of asymmetric syntheses. Ranked fourth in this hit list comes a review on nitroaliphatic compounds that appeared in 1979 in this very journal. Missing in Table 1 are the overviews about his more recent areas of interest, polyhydroxyalkanoates, selfregeneration of stereocenters, chiral dendrimers, TADDOLs, and $\beta$-peptides. Since they were published during the past ten years, these are obviously at a disadvantage compared to the earlier work, but it is easy to predict that they will sooner or later reach the same illustrious status as their predecessors.

The picture changes somewhat when original papers are also taken into consideration. Due to the cornucopia of original contributions from the Seebach group we extended our statistic to include the 20 most cited papers, which makes sense because there is no pronounced drop-off in the number of citations (Table 2). Evaluating the entries in Table 2 [94-113], articles dealing with S-stabilized carbanions (entries 1, 2, $10,15)$ have the lion's share with regard to the number of citations, with the 1975 full paper on the generation and synthetic applications of metallated 1,3-dithianes heading the list. Three of the most cited publications from Table 2 describe applications of organic titanates in organic synthesis (entries 11, 16, 20), followed by two accounts on the stereoselective alkylation of amino acids using the SRS (self regeneration of stereocenters [54]) principle (entries 4 and 12). $\beta$-Peptides are surprisingly prominent in this hit list in the face of their comparatively recent appearance on the roster of Seebach's research interests (entries 6 and 18), and it does not take much prophecy to predict that this particular topic will be soon linked most closely with Seebach's name, especially since he is going to focus his resources exclusively on this area after his retirement. Also represented in this list are

Table 1. The ten most cited review articles of $D$. Seebach

\begin{tabular}{llccc} 
Entry & Subject & Publ. year & No. of citations & Ref. \\
\hline 1 & Li-enolates & 1988 & 675 & {$[32]$} \\
2 & Umpolung & 1979 & 587 & {$[17]$} \\
3 & Stereochemical descriptors & 1982 & 398 & {$[20]$} \\
4 & Nitroaliphatic compounds & 1979 & 368 & {$[16]$} \\
5 & Trends in organic synthesis & 1990 & 336 & {$[34]$} \\
6 & Organotitanium reagents & 1983 & 277 & {$[21]$} \\
7 & Nucleophilic acylations & 1969 & 265 & {$[5]$} \\
8 & N-Nitrosamines & 1975 & 195 & {$[9]$} \\
9 & Alkylation of heterosubst. acids & 1984 & 168 & {$[26]$} \\
10 & Ti and Zr derivatives in synthesis & 1983 & 151 & {$[22]$}
\end{tabular}


two articles on the solution-phase and solid-state structures of lithium enolates (entries 13 and 14), a field for which he is also well renowned. Further analyzing the hit list, the 301 citations of the 1983 full paper on NMR investigations of organolithium compounds (entry 3 ) will probably even astound people with an intimate knowledge of Seebach's research topics over the past decades. On the other hand, it is actually heartening to notice that the third-most cited original paper was published in his mother tongue German in his much beloved publication organ Helvetica Chimica Acta. His life-long pursuit of universally applicable methods for the synthesis of enantiomerically pure compounds is reflected by the prominence of the article on the use of chiral media as co-solvents (entry 5). In order to popularize his synthetic methodology for the chemical industry, he has always keenly been aware of the need to avoid hazardous chemicals and other materials objectionable from an industrial point of view. This is nicely illustrated by his campaign to replace the carcinogenic hexa$m e t h y l p h o s p h o r i c$ triamide (HMPA) by the safe substitute N,N'-dimethyl-N,N'-propylene $u$ rea (DMPU). As seen from entry 8 , this endeavor has not been in vain. His particular approach to EPC synthesis, namely the effective exploitation of stereogenic centers already provided by nature [13] [34], later led him to the investigation of biopolymers, especially polyhydroxybutyrate (PHB). Entry 19 describes the depolymerization of this microbial storage material yielding enantiomerically pure $(R)$-3-hydroxybutyric acid, a versatile building block for EPC synthesis.

Synthetic chemists familiar with Seebach's methodological achievements will observe that some very influential publications are missing from Table 2. In connection with his work on stabilized carbanions, he was the first to recognize the potential of selenium for organometallic reagents [114]. This particular area of organometallic chemistry has since flourished and led to innumerous useful applications in organic synthesis [115]. Another synthetic trick known by most chemists is the quantitative transformation of an organic halide into the respective organolithium compound using two equiv. of tert.-butyllithium [116]. Although this publication missed the top 20 only by the narrowest margin (140 citations), we interpret its comparatively low impact - considering the remarkable usefulness of this method in terms of the typical fate of standard synthetic procedures. References to it are nowadays only found in advanced textbooks [117]. As with the use of selenium in

Table 2. The 20 most cited original articles of $D$. Seebach

\begin{tabular}{clccc} 
Entry & Subject & Publ. year & No. of citations & Ref. \\
\hline 1 & 2-Lithio-1,3-dithianes & 1975 & 354 & {$[94]$} \\
2 & 1,3-Dithiane & 1965 & 336 & {$[95]$} \\
3 & NMR of organolithium compounds & 1983 & 301 & {$[96]$} \\
4 & Alkylation of amino acids & 1983 & 235 & {$[97]$} \\
5 & Chiral media (DDB) & 1977 & 234 & {$[98]$} \\
6 & Prep. of $\beta$-Peptides & 1996 & 231 & {$[99]$} \\
7 & Chiral Alkoxy-Ti complexes & 1987 & 221 & {$[100]$} \\
8 & DMPU & 1982 & 211 & {$[101]$} \\
9 & Diastereoselective Michael addn. & 1981 & 206 & {$[102]$} \\
10 & Phenylthiomethyllithium & 1966 & 206 & {$[103]$} \\
11 & Transesterifications & 1982 & 190 & {$[104]$} \\
12 & Chiral glycine & 1987 & 183 & {$[105]$} \\
13 & Structure of Li-enolates & 1981 & 180 & {$[106]$} \\
14 & Interaction of Li-enolates with amines & 1985 & 170 & {$[107]$} \\
15 & Silyl-1,3-dithianes & 1967 & 162 & {$[108]$} \\
16 & Ti-TADDOLates & 1992 & 157 & {$[109]$} \\
17 & Aggn. of organolithium compounds & 1984 & 155 & {$[110]$} \\
18 & Secondary structure of $\beta$-Peptides & 1996 & 152 & {$[111]$} \\
19 & Depolymerization of PHB & 1982 & 150 & {$[112]$} \\
20 & Polymer-bound Ti-TADDOLates & 1996 & 145 & {$[113]$} \\
& & & & \\
\hline
\end{tabular}

organic chemistry, D. Seebach was also ahead of his time in the use of enzymes for preparative-scale enantioselective synthesis. Yeast [118] and pig liver esterase [119] were the workhorses for numerous synthetic transformations yielding chiral building blocks for EPC synthesis [30][31][83][87]. A further proven method forever linked with Seebach's name is the solubilization of peptides by addition of inorganic salts. The poor solubility of biopolymers in organic solvents is often an obstacle for synthetic transformations but can be overcome by adding large amounts of lithium chloride or bromide [120]. A prime example for the utilization of this effect was the alkylation of cyclosporin A, a cyclic immunosuppressive undecapeptide [121]. An overview of the various effects of lithium salts, strong bases, and co-solvents in peptide chemistry can be found in [38].

The creative wealth and depth of Dieter Seebach's scientific output is not only reflected by the high esteem for his work which is shown by the number of citations, but also by the uninterrupted flow of scientific papers published year by year. A graphic representation of his productivity over his entire scientific career to date is given in the Fig. In the 25 years as full professor at
ETH Zürich alone, he has published 598 papers, an average of 24 per year, and an achievement to be proud of indeed. Taking into account all 728 publications (as of Aug 1, 2002), Helvetica Chimica Acta by a wide margin has traditionally been his favorite publication organ with 220 contributions in total. As long as it was the journal's common practice to accept papers written in one of the Swiss national languages, he happily exercised this option, publishing his last Helv. Chim. Acta account in his native tongue in 1996. As can be seen from the entries in Table 2, this did not prevent the international community of chemists to take notice of at least some of these publications! Following in this list of publication frequency come Angewandte Chemie with a remarkable number of 103 contributions, Chemische Berichte (79), Chimia (42), and Liebigs Annalen der Chemie (39). Despite this apparent loyalty to a small number of journals that are based in his scientific 'homelands', the total number of journals he has chosen to publish in the meantime amounts to roughly 50 . As can be readily seen from Seebach's publication list, the variety of journals he has graced with his contributions in later years somehow reflects the shift in scientific interests from 
hard-core synthetic work to interdisciplinary borderline subjects like material science or biological chemistry. Starting from his early mechanistic work on S-substituted radicals (EPR studies with isotope-labeled compounds when this was far from routine! [122]), via his interest in the structure and reactivity of lithium enolates [32] and the role of PHB polyphosphate in the formation of ion channels [123] to the structural [124][125] and biological aspects [126] [127] of $\beta$-peptides, among numerous others, his approach has been unique in that it always came from the chemist's perspective.

For the many generations of chemists educated at ETH over the past 25 years, Prof. Seebach's significance as a teacher will be at least as high as his visibility as one of the leading researchers in chemistry. One of the pervading trademarks of his numerous classes has been his obvious keenness in enhancing the subject matter by information gathered from his extensive study of the current literature, a constant source of unrest for his teaching assistants who always had to be aware of sudden turns when small addenda to the teaching records were asked for at short notice. The numerous lectureships and visiting professorships [2] bear witness to his outstanding ability to inspire audiences by his animated presentations. This extraordinary gift is also well documented by the more than 840 seminars he has given on all five continents during his career. Consequently, all these activities and commitments have led to a plethora of prestigious distinctions and honors too numerous to specify in this particular context, and much valued in equal measure [2]. His standing as a lecturer is also shown by the many seminars and special courses he has given for audiences rather concerned with the applied aspects of chemistry. Another facet of this relationship to chemical industry has been his long and fruitful activity as a consultant and board member of two Swiss-based companies. As a result of his concern for the practical aspects of chemistry, more than 40 patents have so far emanated from the many discussions he has led with researchers at the industrial front all over the world.

Another facet of Seebach's influence as a researcher and teacher is the significant number of co-workers who were invariably stamped by his unique enthusiasm for chemistry. Altogether, 145 Ph.D. students, more than 90 post-doctoral scholars and a large number of academic guests were at some time part of the Seebach 'empire'. This large number of former co-workers has made a marked impact on the academic community as well as on chemical industry. While the larger part of these embarked on a career in industry, many of them now occupying leading positions, a significant portion remained in academia. Of the postdoctoral scholars, roughly 40 are now active as lecturers or professors, mainly in Germany, Great Britain, and the United States. Of his Ph.D. students, eight currently hold a professorship: M. Braun (Düsseldorf), D. Enders (Aachen), R. Häner (Bern), E. Hungerbühler (Muttenz), P. Knochel (München), M. Pohmakotr (Bangkok), P. Renaud (Bern), and A. Studer (Marburg). As genuine disciples of their master, they are forming the first generation of the Seebach school of chemistry.
It goes without saying that such a tremendous commitment to science needs to be balanced by a private environment shielding the scholar from day-to-day duties. For more than four decades, his wife Inge has devoted herself single-mindedly to this task. Together with their two sons, Jörg and Lutz, their daughter Petra, and their respective partners she maintains the surroundings from which he can draw the strength to cope with a grueling schedule. In recent years, his two grand-daughters, Nora and Clara, have further enriched his family life. An additional source of recreational activity are the daily hours of a swimming workout to which he devotes himself whenever possible. This beloved habit sometimes nonplusses his hosts at universities abroad when asked to find an accommodation equipped with a facility that can meet his exacting demands. Another relaxing task is the search for gourmet restaurants and vineyards all over Europe which also serves as a welcome opportunity to drive one of his cars - for 25 years he has favored the products of a latterly German-American manufacturer - to the limits. In effect, his home is also a kind of gourmet restaurant with his wife Inge as chef de cuisine and himself as the sommelier guarding a huge and well-assorted wine cellar. The happy few who have been lucky to enjoy this couple's hospitality bear testimony to that quality, and naturally such an invitation has always carried a special distinction.

This retrospective account is not intended to signify a final appreciation on Prof. Dieter Seebach's scientific career, but rather a progress report on the occasion of his 65th birthday and the forthcoming

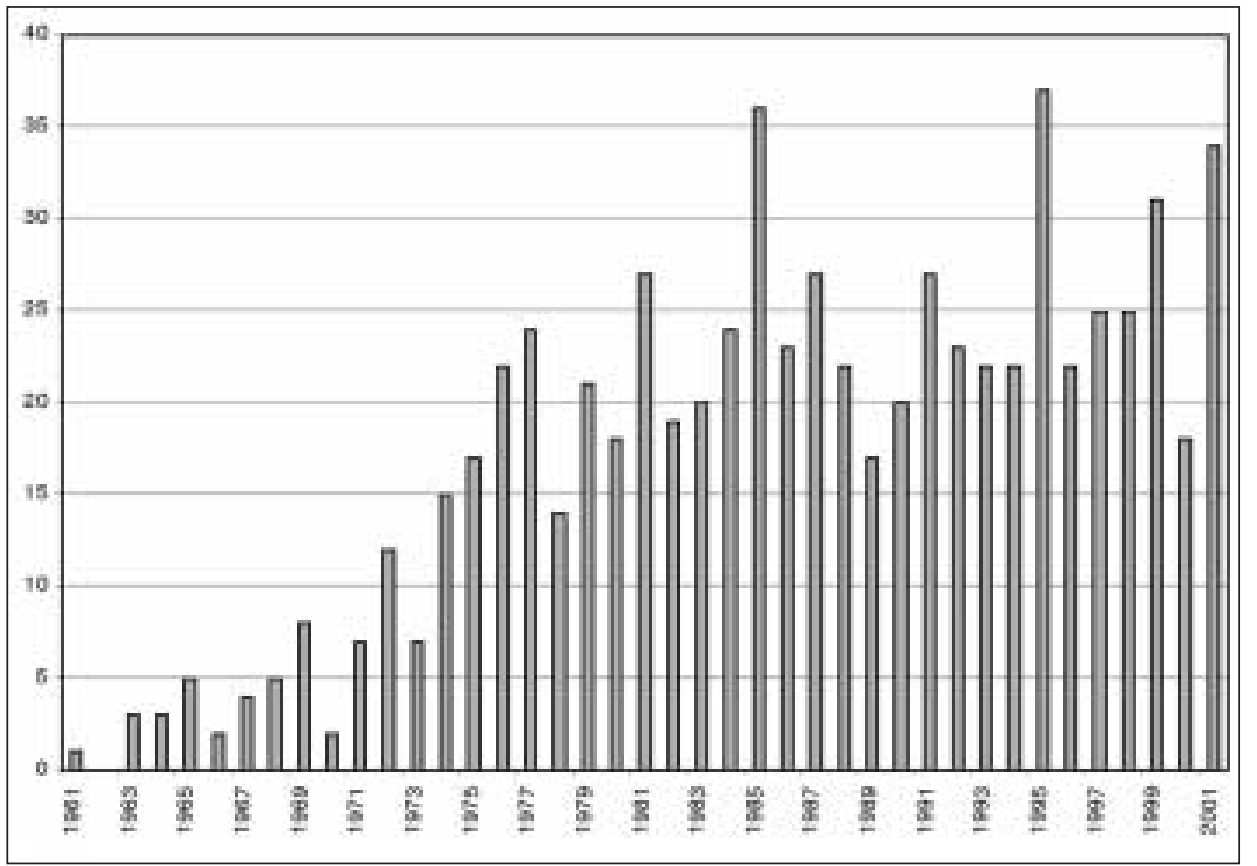

Fig. Number of publications per year by $D$. Seebach from 1961 to 2001 . The total number amounts to 711 [2]. 
retirement from his ETH chair. Given his seemingly inexhaustible creativity and productivity, it is safe to expect further scientific milestones originating from his research. The authors of this homage, themselves members of the scientific Seebach family, would like to join the felicitators' chorus and wish him the very best personally as well as scientifically for the coming era [128].

Albert K. Beck and Dietmar A. Plattner Laboratorium für Organische Chemie ETH Hönggerberg, HCI

CH-8093 Zürich

Received: August 28, 2002

[1] For a more extended summary of Dieter Seebach's career, see: 'Wer ist's?', Nachr. Chem. Tech. Lab. 1995, 43, 714-715; A.K. Beck, J.L. Matthews, 'Full of Enthusiasm for Chemistry - Dieter Seebach Reaches 60', Chimia 1997, 51, 810-814.

[2] The complete list of D. Seebach's publications, awards, and lectureships can be found on his homepage http://infosee.ethz.ch/seebach/seebach.html

[3] D. Seebach, 'Gespannte polycyclische Systeme aus Drei-und Vierring-Bausteinen', Angew. Chem. 1965, 77, 119-129; Angew. Chem. Int. Ed. Engl. 1965, 4, 121-131.

[4] D. Seebach, 'Die 'Woodward-HoffmannRegeln'. Orbitalsymmetriebetrachtungen bei synchron ablaufenden Valenzisomerisierungen und Cycloadditionen'. Fortschr. Chem. Forsch. 1968, 11, 177-215.

[5] D. Seebach, 'Methoden und Möglichkeiten der nucleophilen Acylierung', Angew. Chem. 1969, 81, 690-700; Angew. Chem. Int. Ed. Engl. 1969, 8, 639-649.

[6] D. Seebach, 'Nucleophile Acylierung mit 2-Lithium-1,3-dithianen bzw. -1,3,5-trithianen', Synthesis 1969, 1, 17-36.

[7] D. Seebach, 'Methoden zur Herstellung und Umwandlung isocyclischer VierringVerbindungen', in Methoden der Organischen Chemie (Houben-Weyl), Band IV/4, Ed. E. Müller, Georg Thieme Verlag, Stuttgart 1971, p. 1-443.

[8] D. Seebach, M. Kolb, 'Umpolung (dipole inversion) of carbonyl reactivity', Chem. Ind. (London), 1974, 687-692.

[9] D. Seebach, D. Enders, 'Umpolung der Reaktivität von Aminen. Nucleophile $\alpha$-sek.-Aminoalkylierung über metallierte Nitrosamine', Angew. Chem. 1975, 87, 1-18; Angew. Chem. Int. Ed. Engl. 1975, $14,15-32$

[10] D. Seebach, 'Neue links- und rechtshändige Werkzeuge für den Chemiker', in ' 25 Jahre Fonds der Chemischen Industrie 1950-1975', Schriftenreihe des Verbands der Chemischen Industrie, Fonds der Chemischen Industrie, Frankfurt, 1975, p. 13-29.
[11] D. Seebach, 'Neue Wege in der Organischen Synthese?', in '25 Jahre Fonds der Chemischen Industrie 1950-1975', Schriftenreihe des Verbands der Chemischen Industrie, Fonds der Chemischen Industrie, Frankfurt, 1975, p. 57-63.

[12] D. Seebach, K.-H. Geiss, 'New Applications of Organometallic Reagents in Organic Synthesis', in J. Organomet. Chem., Library 1, Ed. D. Seyferth, Elsevier Scientific Publishing Company, Amsterdam, 1976, p. 1-92.

[13] D. Seebach, H.-O. Kalinowski, 'Enantiomerenreine Naturstoffe und Pharmaka aus billigen Vorläufern (Chiral Pool). Zur Frage der chiral ökonomischen und ökologischen Totalsynthese', Nachr. Chem. Techn. 1976, 24, 415-418.

[14] D. Seebach, K.-H. Geiß, M. Kolb, A.K. Beck, 'Verwendung von Schwefel- und Selenderivaten in der Organischen Synthese', in Modern Synthetic Methods 1976, Vol. 1, Ed. R. Scheffold, Sauerländer AG, Aarau, 1976, p. 173-299.

[15] B.-T. Gröbel, D. Seebach, 'Umpolung of the Reactivity of Carbonyl Compounds Through Sulfur Containing Reagents', Synthesis 1977, 357-402.

[16] D. Seebach, E.W. Colvin, F. Lehr, T. Weller, 'Nitroaliphatic Compounds - Ideal Intermediates in Organic Synthesis?', Chimia 1979, 33, 1-18.

[17] D. Seebach, 'Methoden der Reaktivitätsumpolung', Angew. Chem. 1979, 91, 259-278; Angew. Chem. Int. Ed. Engl. 1979, 18, 239-258.

[18] D. Seebach, E. Hungerbühler, 'Syntheses of Enantiomerically Pure Compounds (EPC-Syntheses). - Tartaric Acid, an Ideal Source of Chiral Building Blocks for Synthesis?', in Modern Synthetic Methods 1980, Vol. 2, Ed. R. Scheffold, Salle + Sauerländer, Frankfurt/Aarau, 1980, p. 91-173.

[19] D. Seebach, M. Pohmakotr, 'Generation of Dienone and Trienone Dianion Derivatives' Tetrahedron 1981, 37, 4047-4058 (Tetrahedron Symposia-in-Print No. 2 on 'New General Synthetic Methods').

[20] D. Seebach, V. Prelog, 'Spezifikation des sterischen Verlaufs von asymmetrischen Synthesen', Angew. Chem. 1982, 94, 696-702; Angew. Chem. Int. Ed. Engl. 1982, 21, 654-660.

[21] B. Weidmann, D. Seebach, 'Organometallverbindungen von Titan und Zirconium als selektive nucleophile Reagentien für die Organische Synthese', Angew. Chem. 1983, 95, 12-26; Angew. Chem. Int. Ed. Engl. 1983, 22, 31-45.

[22] D. Seebach, B. Weidmann, L. Widler, 'Titanium and Zirconium Derivatives in Organic Synthesis. A Review with Procedures', in Modern Synthetic Methods 1983, Vol. 3, Ed. R. Scheffold, Salle + Sauerländer (Aarau, Switzerland) and J. Wiley and Sons (New York, USA), 1983, p. 217-353.

[23] D. Seebach, J.-J. Lohmann, M.A. Syfrig, M. Yoshifuji, 'Alkylation of the Isoquinoline Skeleton in the 1-Position', Tetrahedron 1983, 39, 1963-1974 (Tetrahedron Symposia-in-Print No. 9 on 'Heteroatom-
Directed Metallations in Heterocyclic Synthesis').

[24] D. Seebach, A.K. Beck, M. Schiess, L. Widler, A. Wonnacott, 'Some recent advances in the use of titanium reagents for organic synthesis', Pure Appl. Chem. 1983, 55, 1807-1822.

[25] D. Seebach, A. Hidber, 'Synthese bei Temperaturen unter $-80{ }^{\circ} \mathrm{C}$ ', Chimia 1983, 37, 449-462.

[26] D. Seebach, R. Naef, G. Calderari, ' $\alpha$-Alkylation of $\alpha$-Heterosubstituted Carboxylic Acids without Racemization. EPC-Syntheses of Tertiary Alcohols and Thiols', Tetrahedron 1984, 40, 1313-1324 (Tetrahedron Symposia-in-Print No. 15 on 'Synthesis of Chiral Non-Racemic Compounds').

[27] D. Seebach, 'Crystal Structures and Stereoselective Reactions of Organic Lithium Derivatives', in Proceedings of The Robert A. Welch Foundation Conferences on Chemical Research. XXVII. Stereospecificity in Chemistry and Biochemistry, Nov. 7-9, 1983, Houston, Texas 1984, p. 93-145.

[28] D. Seebach, 'New applications of organometallic derivates of $\mathrm{Li}, \mathrm{Mg}, \mathrm{B}, \mathrm{Al}$, $\mathrm{Si}$, Ti \& V in selective syntheses' in 'Organic Synthesis: an interdisciplinary challenge', Eds. J. Streith, H. Prinzbach, G. Schill (Proceedings of the 5th IUPAC Conference on Organic Synthesis, Freiburg/Breisgau, 1984) Blackwell Scientific Publications Ltd., Oxford, GB, 1985, p. 77-99.

[29] D. Seebach, G. Calderari, P. Knochel, 'Trifluoroacetoxy-phenylselenation of nitroolefins. Regioselective preparation of nitroallylic alcohol derivatives and their use as multiple coupling reagents', Tetrahedron 1985, 41, 4861-4872 (Tetrahedron Symposia-in-Print No. 23 on 'Recent Aspects of Organoselenium Chemistry').

[30] D. Seebach, R. Imwinkelried, T. Weber, 'EPC Syntheses with C,C Bond Formation via Acetals and Enamines', in Modern Synthetic Methods 1986, Vol. 4, Ed. R. Scheffold, Springer Verlag Berlin, Heidelberg, New York, Tokyo, 1986, p. 125-259.

[31] D. Seebach, S. Roggo, J. Zimmermann, 'Biological-Chemical Preparation of 3Hydroxycarboxylic Acids and Their Use in EPC-Syntheses', in 'Stereochemistry of Organic and Bioorganic Transformations', Workshop Conferences Hoechst, Vol. 17, Eds. W. Bartmann, K.B. Sharpless, Verlag Chemie, Weinheim, 1987, p. 85-126.

[32] D. Seebach, 'Struktur und Reaktivität von Lithiumenolaten, vom Pinakolon zur selektiven C-Alkylierung von Peptiden Schwierigkeiten und Möglichkeiten durch komplexe Strukturen', Angew. Chem. 1988, 100, 1685-1715; Angew. Chem. Int. Ed. Engl. 1988, 27, 1624-1654.

[33] C. Betschart, D. Seebach, 'Anwendungen niedervalenter Titan-Reagentien in der Organischen Synthese', Chimia 1989, 43, 39-49.

[34] D. Seebach, 'Organische Synthese wohin?', Angew. Chem. 1990, 102, 1363-1409; Angew. Chem. Int. Ed. Engl. 1990, 29, 1320-1367. 
[35] D. Seebach, 'How We Stumbled Into Peptide Chemistry', Aldrichimica Acta 1992, 25, 59-66.

[36] H.-M. Müller, D. Seebach, 'Poly(hydroxyfettsäureester), eine fünfte Klasse von physiologisch bedeutsamen organischen Biopolymeren?', Angew. Chem. 1993, 105, 483-509; Angew. Chem. Int. Ed. Engl. 1993, 32, 477-502.

[37] E. Juaristi, A.K. Beck, J. Hansen, T. Matt, T. Mukhopadhyay, M. Simson, D. Seebach, 'Enantioselective Aldol and Michael Additions of Achiral Enolates in the Presence of Chiral Lithium Amides and Amines', Synthesis 1993, 1271-1290.

[38] D. Seebach, A.K. Beck, A. Studer, 'Some Effects of Lithium Salts, of Strong Bases, and of the Cosolvent DMPU in Peptide Chemistry, and Elsewhere', in Modern Synthetic Methods 1995, Vol. 7, Eds. B. Ernst, C. Leumann, VHCA Verlag Helvetica Chimica Acta, Basel/VCH Weinheim, 1995, p. 1-178.

[39] A. Studer, D. Seebach, '1-Benzoyl-2-tbutyl-3,5-dimethyl-4-imidazolidinone', in 'Encyclopedia of Reagents for Organic Synthesis', Ed.-in-Chief L. Paquette, Vol. 1, J. Wiley \& Sons, Chichester, 1995, p. 306-308.

[40] A.R. Sting, D. Seebach, '(2S,4S)-3-Benzoyl-2-t-butyl-4-methyl-1,3-oxazolidin5-one', in 'Encyclopedia of Reagents for Organic Synthesis', Ed.-in-Chief L. Paquette Vol. 1, J. Wiley \& Sons, Chichester, 1995, p. 308-309.

[41] A. Studer, D. Seebach, ' $t$-Butyl 2-t-Butyl3-methyl-4-oxo-1-imidazolidinecarboxylate', in 'Encyclopedia of Reagents for Organic Synthesis', Ed.-in-Chief L. Paquette Vol. 2, J. Wiley \& Sons, Chichester, 1995, p. 852-854.

[42] A.K. Beck, D. Seebach, '(R)-2-t-Butyl-6methyl-4H-1,3-dioxin-4-one', in 'Encyclopedia of Reagents for Organic Synthesis', Ed.-in-Chief L. Paquette, Vol. 2, J. Wiley \& Sons, Chichester, 1995, 929-931.

[43] A.R. Sting, D. Seebach, ' $(R, R)-2-t$-Butyl5-methyl-1,3-dioxolan-4-one', in 'Encyclopedia of Reagents for Organic Synthesis', Ed.-in-Chief L. Paquette, Vol. 2, J. Wiley \& Sons, Chichester, 1995, 931-933.

[44] R.E. Marti, D. Seebach, 'O,O-Dilithio-1nitropropene', in 'Encyclopedia of Reagents for Organic Synthesis', Ed.-inChief L. Paquette, Vol. 3, J. Wiley \& Sons, Chichester, 1995, 1946-1948.

[45] A.K. Beck, D. Seebach, ' $N, N$ '-Dimethylpropyleneurea', in 'Encyclopedia of Reagents for Organic Synthesis', Ed.-inChief L. Paquette, Vol. 3, J. Wiley \& Sons, Chichester, 1995, 2123-2127.

[46] R. Dahinden, A.K. Beck, D. Seebach, '2,2-Dimethyl- $\alpha, \alpha, \alpha$ ', $\alpha$ '-tetraphenyl-1,3dioxolane-4,5-dimethanolatotitanium Diisopropoxide', in 'Encyclopedia of Reagents for Organic Synthesis', Ed.-in-Chief L. Paquette, Vol. 3, J. Wiley \& Sons, Chichester, 1995, 2167-2170.

[47] R.E. Marti, D. Seebach, 'Lithium $\alpha$-Lithiomethanenitronate', in 'Encyclopedia of Reagents for Organic Synthesis', Ed.in-Chief L. Paquette, Vol. 5, J. Wiley \& Sons, Chichester, 1995, 3138-3140.
[48] A.K. Beck, R. Dahinden, D. Seebach, 'Mesityllithium', in 'Encyclopedia of Reagents for Organic Synthesis', Ed.-inChief L. Paquette, Vol. 5, J. Wiley \& Sons, Chichester, 1995, 3275-3276.

[49] J. Podlech, D. Seebach, ' $(R)$-Methyl 2-tbutyl-3 $(2 H)$-oxazolecarboxylate', in 'Encyclopedia of Reagents for Organic Synthesis', Ed.-in-Chief L. Paquette, Vol. 5, J. Wiley \& Sons, Chichester, 1995, 3452-3453.

[50] A.K. Beck, R. Dahinden, D. Seebach, 'Methyl 4-Nitrobutanoate', in 'Encyclopedia of Reagents for Organic Synthesis', Ed.-in-Chief L. Paquette, Vol. 5, J. Wiley \& Sons, Chichester, 1995, 3549-3550.

[51] A.K. Beck, R.E. Marti, D. Seebach, 'Methyl 3-Nitropropanoate', in 'Encyclopedia of Reagents for Organic Synthesis', Ed.-in-Chief L. Paquette, Vol. 5, J. Wiley \& Sons, Chichester, 1995, 3551-3552.

[52] A.K. Beck, D. Seebach, 'Trimethylsilyl Methanenitronate', in 'Encyclopedia of Reagents for Organic Synthesis', Ed.-inChief L. Paquette, Vol. 7, J. Wiley \& Sons, Chichester, 1995, 5270-5273.

[53] D. Seebach, A. Brunner, B.M. Bachmann, T. Hoffmann, F.N.M. Kühnle, U.D. Lengweiler, 'Biopolymers and -oligomers of (R)-3-Hydroxyalkanoic Acids - Contributions of Synthetic Organic Chemists', Ernst Schering Research Foundation, 1995, 28, 7-98.

[54] D. Seebach, A.R. Sting, M. Hoffmann, 'Die Selbstregeneration von Stereozentren $(S R S)$ - Anwendungen, Grenzen und Preisgabe eines Syntheseprinzips', $A n$ gew. Chem. 1996, 108, 2880-2921; Angew. Chem. Int. Ed. Engl. 1996, 35, 2708-2748.

[55] D. Seebach, A.K. Beck, 'Catalytic Enantioselective Reactions from Research to Application. Diarylmethanol-Containing Auxiliaries as a Study Case', Chimia 1997, 51, 293-297.

[56] D. Seebach, J.L. Matthews, ' $\beta$-Peptides: a surprise at every turn', Chem. Commun. 1997, 2015-2022.

[57] D. Seebach, P.B. Rheiner, G. Greiveldinger, T. Butz, H. Sellner, 'Chiral Dendrimers', Top. Curr. Chem. 1998, 197, 125-164.

[58] D. Seebach, M.G. Fritz, 'Detection, synthesis, structure, and function of oligo(3hydroxyalkanoates): contributions by synthetic organic chemists', Int. J. Biol. Macromol. 1999, 25, 217-236.

[59] S. Abele, D. Seebach, 'Preparation of Achiral and of Enantiopure Geminally Disubstituted $\beta$-Amino Acids for $\beta$-Peptide Synthesis', Eur. J. Org. Chem. 2000, $1-15$.

[60] D. Seebach, 'TADDOLs - from Enantioselective Catalysis to Dendritic Cross Linkers to Cholesteric Liquid Crystals', Chimia 2000, 54, 60-62.

[61] D. Seebach, 'Forschung - eine Fahrt ins Blaue', Chimia 2000, 54, 751-758.

[62] D. Seebach, 'From Peroxides to Synthetic Methodology and Stereoselectivity to $\beta$ and $\gamma$-Peptide Helices', Articles in Medicine and Science I, The 1999 and 2000 King Faisal International Prize, King Faisal Centre for Research and Islamic
Studies, Riyad, Saudi Arabia, 2000, p. 53-72.

[63] D. Seebach, A.K. Beck, A. Heckel, 'TADDOLe, ihre Derivate und Analoga - vielseitige chirale Hilfsstoffe', Angew. Chem. 2001, 113, 96-142; Angew. Chem. Int. Ed. 2001, 40, 92-138.

[64] D. Seebach, A.K. Beck, M. Rueping, J.V. Schreiber, H. Sellner, 'Excursion of Synthetic Organic Chemists to the World of Oligomers and Polymers', Chimia 2001, 55, 98-103.

[65] D. Seebach, M. Albert, P.I. Arvidsson, M. Rueping, J.V. Schreiber, 'From the Biopolymer PHB to Biological Investigations of Unnatural $\beta$ - and $\gamma$-Peptides', Chimia 2001, 55, 345-353.

[66] D. Seebach, A.K. Beck, A. Heckel, 'TADDOL and Its Derivatives - Our Dream of Universal Chiral Auxiliaries', Essays in Contemporary Chemistry: From Molecular Structure towards Biology', Eds. G. Quinkert, M.V. Kisakürek, VHCA Zürich, Wiley-VCH Weinheim, 2001, p. 283-306.

[67] D. Seebach, M. Rüping, 'Neuartige Peptide und Proteine: Neue Molekül-Welten mit $\beta$-Peptiden', Bulletin ETH Zürich, 282, September 2001, 18-21.

[68] D. Seebach, A.K. Beck, M. Brenner, C. Gaul, A. Heckel, 'From Synthetic Methods to $\gamma$-Peptides - From Chemistry to Biology', Chimia 2001, 55, 831-838.

[69] The results of searches (July 11, 2002) in SciFinder Scholar 2001 (Database CA), STN CA and SCISEARCH (combined author/citation search) have been used in the preparation of this article. As for the citation statistics, a specific approach was taken for the papers that appeared in Angewandte Chemie due to the ambiguities experienced with citations of the German and International Edition of this particular journal. In order to avoid double count, a cited reference search in Web of Science (SCI-EXPANDED, Aug 16, 2002) was conducted on Angewandte publications with the author "Seebach D", and for each hit the citations for the German and English version were merged. The number of citations in Table 1 and 2 represent a lower bound since only the hits with correct volume and page number of the respective publication were taken into account.

[70] R. Fitzi, D. Seebach, 'Resolution and Use in $\alpha$-Amino Acid Synthesis of Imidazolidinone Glycine Derivatives', Tetrahedron 1988, 44, 5277-5292 (Tetrahedron Symposia-in-Print No. 33 on ' $\alpha$-Amino Acid Synthesis').

[71] J.L. von dem Bussche-Hünnefeld, D. Seebach, 'Enantioselective Preparation of sec. Alcohols from Aldehydes and Dialkyl Zinc Compounds, Generated in situ from Grignard Reagents, Using Substoichiometric Amounts of TADDOL-Titanates', Tetrahedron 1992, 48, 5719-5730 (Tetrahedron Symposia-in-Print No. 47 on 'Organotitanium Reagents in Organic Chemistry').

[72] D. Seebach, M. Hayakawa, J.-i. Sakaki, W.B. Schweizer, 'Derivatives of $\alpha, \alpha, \alpha^{\prime}, \alpha^{\prime}$-Tetraaryl-2,2-dimethyl-1,3-dioxolan-4,5-dimethanol (TADDOL) Con- 
taining Nitrogen, Sulfur, and Phosphorus Atoms. New Ligands and Auxiliaries for Enantioselective Reactions', Tetrahedron 1993, 49, 1711-1724 (Tetrahedron Symposia-in-Print No. 49 on 'Synthesis of Optically Active Compounds - Prospects for the 21st Century').

[73] D. Seebach, A.K. Beck, B. Schmidt, Y.M. Wang, 'Enantio- and Diastereoselective Titanium-TADDOLate Catalyzed Addition of Diethyl and bis(3-Buten-1-yl) Zinc to Aldehydes. A Full Account with Preparative Details', Tetrahedron 1994, 50, 4363-4384 (Tetrahedron Symposia-inPrint No. 54 on 'Catalytic Asymmetric Addition Reactions').

[74] B. Weber, D. Seebach, 'Highly Enantioselective Addition of Primary Alkyl Grignard Reagents to Carbocyclic and Heterocyclic Arylketones in the Presence of Magnesium TADDOLate. Preparative and Mechanistic Aspects', Tetrahedron 1994, 50, 6117-6128 (Tetrahedron Symposiain-Print No. 55 on 'Mechanistic Aspects of Polar Organometallic Chemistry').

[75] A.R. Sting, D. Seebach, 'Synthesis of $(2 R, 3 S)$ - or $(2 S, 3 R)$-2-Amino-3-trifluoromethyl-3-hydroxyalkanoic Acid Derivatives (Threonine and allo-Threonine Analogs) from Enantiopure 4,4,4-Trifluoro-3-hydroxybutanoic Acid', Tetrahedron 1996, 52, 279-290 (Tetrahedron Symposia-in-Print No. 58 on 'Fluoroorganic Chemistry: Synthetic Challenges and Biomedicinal Rewards').

[76] D. Seebach, A.K. Beck, T. Mukhopadhyay, E. Thomas, 'Diastereoselective Synthesis of Nitroaldol Derivatives', Helv. Chim. Acta 1982, 65, 1101-1133.

[77] E.J. Corey, D. Seebach, '1,3-Dithiane' Organic Syntheses 1970, 50, 72-74; Collective Volume VI, 1988, 556-559.

[78] D. Seebach, A.K. Beck, 'Aldehydes from sym-Trithiane: n-Pentadecanal', Organic Syntheses 1971, 51, 39-43; Collective Volume VI, 1988, 869-872.

[79] D. Seebach, A.K. Beck, 'Cyclic Ketones from 1,3-Dithiane: Cyclobutanone', Organic Syntheses 1971, 51, 76-81; Collective Volume VI, 1988, 316-319.

[80] D. Enders, R. Pieter, B. Renger, D. Seebach, 'Nucleophilic $\alpha$-sec-Aminoalkylation: 2-(Diphenylhydroxymethyl)pyrrolidine', Organic Syntheses 1978, 58, 113-122; Collective Volume VI; 1988, 542-549.

[81] D. Seebach, H.-O. Kalinowski, W. Langer, G. Crass, E.-M. Wilka, 'Chiral Media for Asymmetric Solvent Inductions. $(S, S)$ (+)-1,4-Bis-(dimethylamino)-2,3-Dimethoxybutane from $(R, R)-(+)$-Tartaric Acid Diethyl Ester', Organic Syntheses 1983, 61, 24-34; Collective Volume VII, 1990, $41-50$.

[82] D. Seebach, A. Hidber, 'Enantioselective Addition of Butyllithium in the Presence of the Chiral Cosolvent DDB. (+)-(R)Phenyl-1-pentanol', Organic Syntheses 1983, 61, 42-47; Collective Volume VII, 1990, 447-450.

[83] D. Seebach, M.A. Sutter, R.H. Weber, M.F. Züger, 'Yeast Reduction of Ethyl Acetoacetate: $(S)$-(+)-Ethyl 3-Hydroxybu- tanoate', Organic Syntheses 1985, 63, 1-9; Collective Volume VII, 1990 215-220.

[84] D. Seebach, J. Aebi, D. Wasmuth, 'Diastereoselective $\alpha$-Alkylation of $\beta$-Hydroxycarboxylic Esters through Alkoxide Enolates: (+)-Diethyl (2S,3R)-3-Allyl-2Hydroxysuccinate from (-)-Diethyl $S$ Malate', Organic Syntheses 1985, 63 , 109-120; Collective Volume VII, 1990, 153-159.

[85] R. Imwinkelried, M. Schiess, D. Seebach, 'Diisopropyl (2S,3S)-2,3-O-Isopropylidenetartrate' Organic Syntheses 1987, 65 , 230-235; Collective Volume VIII, 1993 201-204.

[86] R. Imwinkelried, D. Seebach, '3'-Nitro-1phenylethanol by Addition of Methyltriisopropoxytitanium to $\mathrm{m}$-Nitrobenzaldehyde', Organic Syntheses 1989, 67, 180-185.

[87] M. Eberle, M. Missbach, D. Seebach, 'Enantioselective Saponification with Pig Liver Esterase (PLE): (1S,2S,3R)-3-Hydroxy-2-Nitrocyclohexyl Acetate', Organic Syntheses 1990, 69, 19-30.

[88] D. Seebach, A.K. Beck, R. Breitschuh, K. Job, 'Direct Degradation of the Biopolymer Poly $[(R)-3$-Hydroxybutyric Acid] to $(R)$-3-Hydroxybutanoic Acid and its Methyl Ester', Organic Syntheses 1992, 71, 39-47; Collective Volume IX, 1998, $483-487$.

[89] A.K. Beck, S. Blank, K. Job, D. Seebach, T. Sommerfeld, 'Synthesis of (S)-2Methylproline: A General Method for the Preparation of $\alpha$-Branched Amino Acids', Organic Syntheses 1995, 72, 62-73; Collective Volume IX, 1998, 626-632.

[90] A.K. Beck, P. Gysi, L. La Vecchia, D. Seebach, '(4R,5R)-2,2-Dimethyl- $\alpha, \alpha, \alpha$ ', $\alpha$ 'Tetra(naphth-2-yl)-1,3-Dioxolane-4,5Dimethanol from Dimethyl Tartrate and 2Naphthyl-Magnesium Bromide', Organic Syntheses 1999, 76, 12-22.

[91] D. Seebach, H.-F. Chow, R.F.W. Jackson, M.A. Sutter, S. Thaisrivongs, J. Zimmermann, '(+)-11,11'-Di-O-methylelaiophylidene - Preparation from Elaiophylin and Total Synthesis from $(R)$-3-Hydroxybutyrate and (S)-Malate', Liebigs Ann. Chem. 1986, 1281-1308, and lit. cited therein.

[92] D. Seebach, G. Adam, R. Zibuck, W. Simon, M. Rouilly, W.L. Meyer, J.F. Hinton, T.A. Privett, G.E. Templeton, D.K. Heiny, U. Gisi, H. Binde, 'Gloeosporone - A Macrolide Fungal Germination Self-Inhibitor. Total Synthesis and Activity', Liebigs Ann. Chem. 1989, 1233-1240.

[93] M.A. Maestro, M. Sefkow, D. Seebach, 'Total Synthesis of Myxovirescins, 3. Coupling of the Two Key Fragments and Last Steps to Myxovirescins $\mathrm{A}_{1}$ and $\mathrm{M}_{2}$, Liebigs Ann. Chem. 1994, 731-738, and lit. cited therein.

[94] D. Seebach, E.J. Corey, 'Generation and Synthetic Applications of 2-Lithio-1,3dithianes', J. Org. Chem. 1975, 40, 231-237.

[95] E.J. Corey, D. Seebach, 'Carbanionen der 1,3-Dithiane, Reagentien zur C-CVerknüpfung durch nucleophile Substitu- tion oder Carbonyl-Addition', Angew. Chem. 1965, 77, 1134-1135; Angew. Chem. Int. Ed. Engl. 1965, 4, 1075-1077.

[96] D. Seebach, R. Hässig, J. Gabriel, ${ }^{13} \mathrm{C}-$ NMR.-Spektroskopie von Organolithiumverbindungen bei tiefen Temperaturen. Strukturinformation aus der ${ }^{13} \mathrm{C},{ }^{6} \mathrm{Li}-\mathrm{Kop}-$ plung', Helv. Chim. Acta 1983, 66, 308-337.

[97] D. Seebach, M. Boes, R. Naef, W.B. Schweizer, 'Alkylation of Amino Acids without Loss of the Optical Activity: Preparation of $\alpha$-Substituted Proline Derivates. A Case of Self-Reproduction of Chirality', J. Am. Chem. Soc. 1983, 105, 5390-5398.

[98] D. Seebach, H.-O. Kalinowski, B. Bastani, G. Crass, H. Daum, H. Dörr, N.P. Du Preez, V. Ehrig, W. Langer, C. Nüssler, H.-A. Oei, M. Schmidt, 'Herstellung von Hilfsstoffen für die asymmetrische Synthese aus Weinsäure. Addition von Butyllithium an Aldehyde in chiralem Medium', Helv. Chim. Acta 1977, 60, 301-325.

[99] D. Seebach, M. Overhand, F.N.M. Kühnle, B. Martinoni, L. Oberer, U. Hommel, H. Widmer, ' $\beta$-Peptides: Synthesis by Arndt-Eistert Homologation with Concomitant Peptide Coupling. Structure Determination by NMR and CD Spectroscopy and by X-Ray Crystallography. Helical Secondary Structure of a $\beta$-Hexapeptide in Solution and its Stability towards Pepsin', Helv. Chim. Acta 1996, 79, 913-941.

[100] D. Seebach, A.K. Beck, R. Imwinkelried, S. Roggo, A. Wonnacott, 'Chirale Alkoxytitan(IV)-Komplexe für enantioselektive nucleophile Additionen an Aldehyde und als Lewis-Säuren in DielsAlder-Reaktionen', Helv. Chim. Acta 1987, 70, 954-974.

[101] T. Mukhopadhyay, D. Seebach, 'Substitution of HMPT by the Cyclic Urea DMPU as a Cosolvent for Highly Reactive Nucleophiles and Bases', Helv. Chim. Acta 1982, 65, 385-391.

[102] D. Seebach, J. Golinski, 'Synthesis of OpenChain 2,3-Disubstituted 4-nitroketones by Diastereoselective Michael-addition of $(E)$-Enamines to $(E)$-Nitroolefins. A Topological Rule for C, C-Bond Forming Processes between Prochiral Centres', Helv. Chim. Acta 1981, 64, 1413-1423.

[103] E.J. Corey, D. Seebach, 'Phenylthiomethyllithium and Bis(phenylthio)methyllithium', J. Org. Chem. 1966, 31, 4097-4099.

[104] D. Seebach, E. Hungerbühler, R. Naef, P. Schnurrenberger, B. Weidmann, M. Züger, 'Titanate-Mediated Transesterifications with Functionalized Substrates', Synthesis 1982, 138-142.

[105] D. Seebach, E. Juaristi, D.D. Miller, C. Schickli, T. Weber, 'Addition of Chiral Glycine, Methionine, and Vinylglycine Enolate Derivatives to Aldehydes and Ketones in the Preparation of Enantiomerically Pure $\alpha$-Amino- $\beta$-hydroxy Acids', Helv. Chim. Acta 1987, 70, 237-261.

[106] R. Amstutz, W.B. Schweizer, D. Seebach, J.D. Dunitz, 'Tetrameric Cubic Structures of two Solvated Lithium Enolates', Helv. 
Chim. Acta 1981, 64, 2617-2621.

[107] T. Laube, J.D. Dunitz, D. Seebach, 'Über die Wechselwirkung zwischen Lithiumenolaten und sekundären Aminen in Lösung und im Kristall', Helv. Chim. Acta 1985, 68, 1373-1393.

[108] E.J. Corey, D. Seebach, R. Freedman, 'Synthesis of $\alpha$-Silyl Ketones via 1,3Dithianes', J. Am. Chem. Soc. 1967, 89, 434-436.

[109]D. Seebach, D.A. Plattner, A.K. Beck, Y.M. Wang, D. Hunziker, W. Petter, 'On the Mechanisms of Enantioselective Reactions Using $\alpha, \alpha, \alpha^{\prime}, \alpha^{\prime}$-Tetraaryl-1,3dioxolane-4,5-dimethanol(TADDOL)-Derived Titanates: Differences between $\mathrm{C}_{2}-$ and $\mathrm{C}_{1}$-Symmetrical TADDOLs - Facts, Implications and Generalizations', Helv. Chim. Acta 1992, 75, 2171-2209.

[110] W. Bauer, D. Seebach, 'Bestimmung des Aggregationsgrads lithiumorganischer Verbindungen durch Kryoskopie in Tetrahydrofuran', Helv. Chim. Acta 1984, 67, 1972-1988.

[111] D. Seebach, P.E. Ciceri, M. Overhand, B. Jaun, D. Rigo, L. Oberer, U. Hommel, R. Amstutz, H. Widmer, 'Probing the Helical Secondary Structure of Short-Chain $\beta$ Peptides', Helv. Chim. Acta 1996, 79, 2043-2066.

[112] D. Seebach, M. Züger, 'Über die Depolymerisierung von Poly- $(R)$-3-hydroxy-buttersäureester (PHB)', Helv. Chim. Acta 1982, 65, 495-503.

[113] D. Seebach, R.E. Marti, T. Hintermann, 'Polymer- and Dendrimer-Bound TiTADDOLates in Catalytic (and Stoichiometric) Enantioselective Reactions: Are Pentacoordinate Cationic Ti Complexes the Catalytically Active Species?', Helv. Chim. Acta 1996, 79, 1710-1740.

[114] D. Seebach, N. Peleties, 'Mono-, Bis- und Tris(phenylseleno)methyllithium (selenstabilisierte Carbanionen)', Angew. Chem. 1969, 81, 465-466; Angew. Chem. Int. Ed.
Engl. 1969, 8, 450-451.

[115] T. Wirth (Ed.), 'Organoselenium Chemistry - Modern Developments in Organic Synthesis', Top. Curr. Chem. 2000, Vol. 208; D. Liotta (Ed.), 'Organoselenium Chemistry', Wiley, New York, 1987.

[116] D. Seebach, H. Neumann, 'Brom-LithiumAustausch an Vinyl- und Aryl-bromiden mit tert-Butyllithium. Zur Ringerweiterung über Dibromcarbenaddukte', Chem. Ber. 1974, 107, 847-853.

[117] M.B. Smith, J. March, 'March's Advanced Organic Chemistry - Reactions, Mechanisms, and Structure', Fifth Edition, Wiley, New York, 2001.

[118] M.F. Züger, F. Giovannini, D. Seebach, 'Herstellung von (R)-(-)-3-Hydroxy-2methyl-propionsäureethylester durch $\mathrm{He}$ fereduktion von $\alpha$-Formyl-propionsäureethylester', Angew. Chem. 1983, 95, 1024; Angew. Chem. Int. Ed. Engl. 1983, 22, 1012.

[119] D. Seebach, M. Eberle, 'Enantioselective Cleavage of meso-Nitrodiol Diacetates by an Esterase Concentrate from Fresh Pig Liver: Preparation of Useful Nitroaliphatic Building Blocks for EPC Syntheses', Chimia 1986, 40, 315-318.

[120] D. Seebach, A. Thaler, A.K. Beck, 'Solubilization of Peptides in Non-polar Organic Solvents by the Addition of Inorganic Salts: Facts and Implications', Helv.Chim. Acta 1989, 72, 857-867.

[121] D. Seebach, A.K. Beck, H.G. Bossler, C. Gerber, S.Y. Ko, C.W. Murtiashaw, R. Naef, S. Shoda, A. Thaler, M. Krieger, R. Wenger, 'Modification of Cyclosporin A (CS): Generation of an Enolate at the Sarcosine Residue and Reactions with Electrophiles', Helv. Chim. Acta 1993, 76, 1564-1590.

[122] D. Seebach, A.K. Beck, H.B. Stegmann, 'Homolyse der Äthan-C-C-Bindung, Nachweis von Tris(phenylthio)methyl durch ${ }^{13}$ C-Markierung', Angew. Chem. 1971, 83, 534 - 535; Angew. Chem. Int.
Ed. Engl. 1971, 10, 500-501.

[123] S. Das, U.D. Lengweiler, D. Seebach, R.N. Reusch, 'Proof for a nonproteinaceous calcium-selective channel in Escherichia coli by total synthesis from $(R)$-3-hydroxybutanoic acid and inorganic polyphosphate', Proc. Natl. Acad. Sci. USA 1997, 94, 9075-9079.

[124] X. Daura, B. Jaun, D. Seebach, W.F. van Gunsteren, A.E. Mark, 'Reversible Peptide Folding in Solution by Molecular Dynamics Simulation', J. Mol. Biol. 1998 , 280, 925 - 932; X. Daura, K. Gademann, H. Schäfer, B. Jaun, D. Seebach, W.F. van Gunsteren, 'The $\beta$-Peptide Hairpin in Solution: Conformational Study of a $\beta$ Hexapeptide in Methanol by NMR Spectroscopy and MD Simulation', J. Am. Chem. Soc. 2001, 123, 2393-2404.

[125] D. Seebach, Y. R. Mahajan, R. Senthilkumar, M. Rueping, B. Jaun, ' $\beta$-Depsipeptides - the effect of a missing and a weakened hydrogen bond on the stability of the $\beta$-peptidic 3 3 -helix', Chem. Commun. 2002, 1598-1599.

[126] D. Seebach, M. Rueping, P.I. Arvidsson, T. Kimmerlin, P. Micuch, C. Noti, D. Langenegger, D. Hoyer, 'Linear, PeptidaseResistant $\beta^{2} / \beta^{3}$-Di-and $\alpha / \beta^{3}$-Tetrapeptide Derivatives with Nanomolar Affinities to a Human Somatostatin Receptor', Helv. Chem. Acta 2001, 84, 3503-3510.

[127] J.V. Schreiber, J. Frackenpohl, F. Moser, T. Fleischmann, H.-P. Kohler, D. Seebach, 'On the Biodegradation of $\beta$-Peptides', ChemBioChem 2002, 3, 424-432.

[128] The authors would like to acknowledge the compilation of the literature data [69] by Dr. Engelbert Zass, Informationzentrum Chemie Biologie, ETH Zürich, and the polishing of the manuscript by Prof. Matthias Selke, California State University Los Angeles.

\section{The Editorial Board of CHIMIA heartily} congratulates Prof. Dr. Dieter Seebach on the occasion of his 65th birthday. We would also like to thank Prof. Seebach for his continuous support of CHIMIA and wish him all the best for the next new phase in his life and work. 